\title{
A PERFECT DRUG
}

\section{What you don't know can help you.}

\section{BY DAN ERLANSON}

$\mathrm{J}$ effrey rose slowly, scanned the half-dozen people in the darkly panelled boardroom, and sonorously announced: "You all know the good news. It's the bad news I've gathered you to hear."

Alan carefully maintained a neutral composure, but quietly he seethed. It was bad enough for the head of commercialization to call an emergency executive meeting without informing him, the chief executive, what it was about. Now Jeffrey was going to theatrically draw out whatever he was planning to say - and there was nothing Alan could do. Jeffrey had powerful supporters on the board; after all, he had certainly delivered for the company.

"As you know, the launch of Paxpharma has been one of the most successful product rollouts in the history of our industry," Jeffrey continued. "In the crowded field of antidepressants, our drug stands out with the lowest side-effect profile on the market. Uptake has been phenomenal, and we've gone from a struggling mid-tier pharmaceutical company with a looming patent cliff to the darling of Wall Street.

"As you also know, Paxpharma almost didn't launch. The molecule is a nightmare to synthesize, and the size of the phase III trials necessitated a complete reworking of the manufacturing process. Even with the new synthetic route in place, we barely scraped together enough material for the trials."

Alan remembered that period painfully well. The company was being pounded by analysts and investors for its thin pipeline. A new antidepressant wasn't an obvious home-run, but the phase II data were compelling, and they didn't have much else. Manufacturing spent months validating the new production procedure, and when everything was worked out and signed off with the FDA, the factory went into 24/7 production mode. It was expensive, but it paid off: the phase III trials revealed Paxpharma to be just as effective as existing antidepressants, but with a faster onset of action and milder side-effect profile. In particular, there was no evidence of weight gain or sexual dysfunction, two problems that focus groups had shown to be particularly unpopular with competitor drugs.

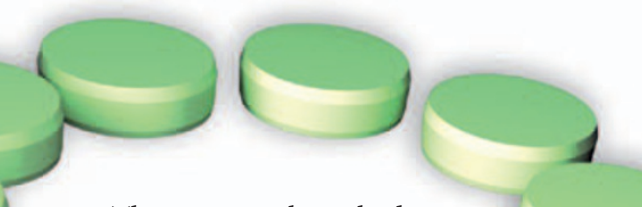

The company launched an aggressive and edgy advertising campaign touting Paxpharma. It worked. One of the ads went viral on YouTube, and the drug got the kind of attention from talk-show hosts and celebrities that can only come about through deserved but dumb luck. There were concerns that demand would outstrip supply, but somehow production increased, and profits soared. Stock analysts who had been calling for changes in leadership suddenly became fawning. Alan couldn't help smiling, remembering his change in fortune.

His reverie was broken by Jeffrey, who was still pontificating. "As I said at the outset, the good news is that the trials were positive. Paxpharma was approved and is now a major commercial success. Now the bad news.

"When the drug was approved, we were at a loss as to how we could scale up production even further. We struggled to make enough material for the pivotal trials, let alone for a launch. And, of course, any significant change in manufacturing procedure would have to be approved by the FDA. We realized we couldn't do it in time."

There was silence in the room as people tried to digest what they had just heard. Alan finally blurted: "But you did. Right?"

"No," said Jeffrey. "We tried, but we couldn't do it."

"What do you mean?" asked Alan, his voice rising tremulously. "We've been selling product for the past 18 months!"

"Yes, we've been selling product," Jeffrey repeated slowly. "But we haven't been selling a drug. We've been selling sugar pills for the past six quarters."

Alan felt his stomach hit the floor. Time

$\rightarrow$ NATURE.COM

Follow Futures on

Facebook at:

go.nature.com/mtoodm seemed to stop. "But... it works," he finally managed, weakly.

Jeffrey shrugged.

"Yes, we were happily surprised by that too. The placebo effect is $\frac{\vec{u}}{\mathscr{}}$ strong with psychoactive drugs. I guess we 학 never realized how strong."

"That's the bad news," Jeffrey continued. "A small team of us have kept this secret until now, and we could probably continue to do so indefinitely, but some new developments require decisions.

"The production difficulties with Paxpharma are well-known, and we've been diligently adding capacity. The new plants are now online, and we believe we can now supply enough active pharmaceutical ingredient to meet demand. The question is, should we?"

Alan shouted: "Of course! Right away - why wouldn't you?"

Jeffrey looked at Alan condescendingly, then gazed slowly around the room. "Think about it. We've been selling a product with no side effects, and people are clearly benefiting: just read the patient testimonials posted everywhere online. Look at the sales figures. "If we switch to selling the actual drug molecule, we'll be putting patients at risk. Sure, the side-effect profile is lower than other drugs out there, but there are side effects with any drug. Worse, these will be especially noticeable to the people who are most benefiting from our product - the patients who have been taking it for months without any problems.

"We will of course continue to manufacture the genuine article as a smokescreen for regulators, but, in the interest of our customers and our shareholders, I recommend continuing to sell placebo." Jeffrey paused before adding, "Of course, the decision is not mine to make."

Alan could feel a dozen eyes on him. The seconds ticked into minutes, and by the time he finally replied, his voice was barely audible.

Dan Erlanson is a chemist trying to discover non-placebo-based drugs in San Francisco, California. He blogs about a tiny niche of drug discovery at http://practicalfragments.blogspot.com. 